6. Кудрявцева К. Композиція i «мова» живопису в станковій картині // Українська академія мистецтва : дослідницькі та науковометодичні праці. Київ : Фенікс, 2013. Вип. 21. С. 167-174.

7. Соловей О..Феномен творчо-педагогічної діяльності / Соловей О. // Мистецтвознавство України: зб. наук. праць. - К.: ін-т пробл. суч. мистецтва АМУ. -2009. - № 10. С. 338-345.

8. Соловей О. Купол Пресвятої Трійці // Художня культура. Актуальні проблеми: науковий вісник. К.: ІПСМ НАМУ, 2010. Вип. 7. - С. 128-150.

9. Соловей О. Мозаїчне панно «Україна Скіфська - Еллада Степова Миколи Стороженка. Архітектоніка пластичного простору // Українська академія мистецтва: Дослідницькі та наук.-метод. праці / НАОМА. Київ, 2018. Вип. 27. С. $21-220$.

DOI https://doi.org/10.30525/978-9934-26-004-9-65

\title{
ХУДОЖНИК НИКОЛАЙ ТРЕГУБ: В БОРЬБЕ ЗА ЧЕЛОВЕКА
}

\author{
Солярская-Комарчук И. О. \\ кандидат философских наук, доиент, \\ дочент кафедры искусствоведческой экспертизы \\ Наџиональной академии руководящих кадров культурь и искусства \\ г. Киев, Украина
}

Среди художников украинского нонкорфомизма имя Николая Трегуба, хотя и имеет некоторую известность, но все же требует особого внимания. Украинский нонконформизм несет в своих глубинах множество течений, ответвлений, но, главное, каждый его мастер был незаурядной личностью, часто интеллектуалом, или, как в случае Николая Трегуба, философом.

Работы художника (их насчитывают более тысячи) были написаны в основном в 70-ых годах прошлого века. Большинство представителей киевского нонконформизма, к которым принадлежал Н. Трегуб, было вынужденно жить тогда в мире двойных стандартов - писать работы, которые не противоречат соцреализму, и, одновременно, писать то, что хотелось выразить, используя собственную образную систему и, соответственно, внедряя новые изобразительные техники. Создавался мир индивидуальных мифологем, и каждый мастер приглашал зрителя проникнуться миром его переживаний. В этой «другой» живописи 246 
техника исполнения (коллаж, ассамбляж, абстракция) создает также подругому и образ, уводя зрителя вглубь, оголяя смысл, разрешая как-бы к нему прикоснуться. Техника исполнения уже не средство, а часть образа.

У Н. Трегуба раздвоенности не было, он всегда писал только то, что хотел, что чувствовал. Поэтому был «ненадежным» в советском обществе, поэтому не смог продолжить обучение в художественном институте после училища, не смог, к сожалению, брать участие в выставках, попав в атмосферу непонимания и уничижения. При жизни художника было всего две выставки (1977, 1978), которые он организовывал вместе с друзьями и единомышленниками. Они были краткосрочными, их сразу закрывали.

Украинский мастер, несмотря на то, что был скромным и чувствительным человеком, был харизматичным, повлияв на многих своих друзей и коллег. Он разговаривал на украинском языке, читал запрещенную литературу, особенно любил стихи украинских поэтов «расстрелянного возрождения» - Е. Плужника, В. Симоненка, М. ДрайХмары, Н. Зерова. Урывки произведений указанных поэтов Н. Тригуб часто включал в свои живописные работы, создавая и углубляя их образное содержание. Писал он и свои тексты. Записи размещал на полотне в нескольких местах. Часто строфы выходят на края рамы.

В 1962 году он познакомился с Вудоном Баклицким, художникомсамородком, который также стал ярким представителем украинского нонконформизма. Именно Н. Трегуб увидел талант В. Баклицкого и повлиял на творческое становление последнего. Трегуб предложил ходить вместе на этюды. «Начались поиски собственного стиля. Было все - и «открытый» заново пуантелизм, и стихийное подражание Ван Гогу, и попытки соединить корень (народный) и крону, и многое другое. Но постепенно была найдена собственная манера работы с пленэром, собственное понимание композиции, навязанное, отчасти, использованием малоподходящих материалов» [4]. Отсутствие полного образования всегда тяготило Н.Трегуба. Как отмечают коллеги, художник зачитывался книгой по истории нидерландской живописи XVII века, хотя работы его совсем другие. Но самообразование помогло ему выработать своеобразную систему художественного изображения, никем не откорректированную. Все его творчество пронизано идеей свободы человека, не приятием агрессии, направленной на уничтожение человеческого достоинства. Поэтому, Н.Трегуб вместе с В.Баклицким стали инициаторами создания творческого объединения «New Bent», a вскоре примыкают к группе «Рух», где собрались представители 
киевского андеграунда. Все эти творческие объединения были недолгими и вскоре распались под натиском силовых структур.

Уже тогда можно было заметить, что киевский нонконформизм был разным. Существовал «рафинированный» андеграунд, который представляли профессиональные художники (круг Левича-Лымарева). Трегуб и Баклицкий формально принадлежали этому направлению, но становление их мастерства происходило вне академической школы. Некоторые украинские искусствоведы называют их художникамисамородками. Как результат - совершенно своеобразная форма «запрещенного» искусства. В среде художников андеграунда они «резко выделялись из неё мощью таланта, творческого темперамента, нацеленностью на создание искусства, не отягощенного никакими компромиссами с системой» [2]. Интересно, что их также нельзя отнести к группе национально настроенных художников-шестидесятников (А. Горская, В. Зарицкий, О. Заливаха и др.), творческие принципы которых формировались под влиянием искусства М. Бойчука. Трегуб и Баклицкий, сами не подозревая, стали яркими представителями украинского постмодернизма. Николай Трегуб был не только носителем традиций украинской культуры, но и боролся против всякого умаления её ценностей и достижений. Однако, «себя и свои произведения Николай ощущал, как часть Вселенной, которая безгранична и которая все видит, поэтому был честным перед собой и людьми, не признавая фальши и обмана» [3]. Трегуб, как и его друг Баклицкий, не привязывались к какому-то периоду, месту, событиям, в частном они видели проявление универсального - «и Микола, и Виля существовали сразу в трех временах: прошлом, будущем и настоящем. Тригуб общался, как с приятелем, с Плужником, а Баклицкий выпивал с Модильяни, и при этом знал, что его работы когда-нибудь будут в музеях» [4].

Можно утверждать, что творчество Н.Тригуба стало вариантом своеобразного украинского живописного экзистенциализма. Его «Ню в горячем» (1978 г.) по драматизму звучания созвучно образу «Шагающего человека» (1961 г.) швейцарского скульптора А. Джакометти, на творчество которого повлияли идеи философов Ж.-П.Сартра, А. Камю. Как считают исследователи, скульптор, болевший эпилепсией, переживший ужасы Второй мировой и автокатастрофу, много раздумывал о смерти, и «году к 1947 Джакометти окончательно осознал и почувствовал уязвимость и беззащитность человека» [1].

Тема смерти, ценности и беззащитности человеческой жизни также ярка в работах Н.Трегуба. На протяжении своего короткого жизненного пути (1943-1984 гг.) он в постоянной борьбе, понимая абсурдность 
самого понятия «режим» и не принимая доминирование последнего в жизни человека. Осмысление смерти стало одной из главных тем в живописи Трегуба («Пьета», «Маска», «Мы тебя не...», «Седое прошлое»), к ней художника подталкивала сама жизнь. Не успев появиться на свет в 1943 году, художник потерял отца на фронте. Ужасы войны наложились на семейные трагедии времен Голодомора (1932-1933 гг.) - от голода умерли родители матери и четверо её братьев и сестер («Двое. Портрет мамы Ярины и тётушки Ганны», «Тётя Олена с тётей Оксаной»). После войны мать должна была до изнеможения работать в колхозе, оставляя больного туберкулезом сына в доме. Любимые украинские поэты художника также были репрессированы и убиты. Советской властью убивались не только люди, уничтожалась самобытность истории и культуры Украины. Во всех этих трагедиях терялась ценность человеческой жизни, гуманность, свобода, любовь, оставалось место только страху перед блюстителями советского режима. Поэтому изображение черепа или маски (обескровленного лица) характерны для творчества Н.Трегуба.

В творчестве украинского художника особое место занимает портрет, жанр, который дорожит личностью, внутренним миром человека («Портрет дядьки Федора в сером пиджаке», «Портрет литератора», «Срисовано для Валентина», «Портрет Зарубиной», «Задумчивая»). «Художники андеграунда прежде всего заботились о сохранении человеческой индивидуальности в условиях коллективистского нивелирования. Поэтому они уделяли особое внимание портретному жанру, обогатив его стилистически» [5].

Среди портретируемых следует выделить образ Выдубицкого монастыря (г. Киев), силуэты которого угадываются во многих работах Н.Трегуба. Святыня стала для художника последним оплотом в нелегкой борьбе за свободу быть Человеком, а также местом, где мастер в отчаянье покончил с жизнью.

\section{Литература:}

1. Альберто Джакометти. Гуманизм как экзистенциализм. 2012. URL: https://adindex.ru/publication/gallery/2012/11/12/94537.phtml (дата обращения: 20.11.2020).

2. Голуб О. Відшукування потойбічних сфер. 2003. URL: https://zn.ua/ukr/SOCIUM/vidshukuvannya_potoybichnih_sfer.html____ата обращения: 20.11.2020). 
3. Другая ветвь Киевского андеграунда. 2011. URL: https://antikvar.ua/drugaya-vetv-kievskogo-andegraunda/ (дата обращения: 20.11.2020).

4. Леоненко Н., Вайсберг В. Запоздалый некролог. 2011. URL: https://artukraine.com.ua/a/zapozdalyy-nekrolog/\#.X7apcGj7Q2w ， (дата обращения: 20.11.2020).

5. Петро Яковенко. Згадуючи обличчя 70-x. 2017. URL: http://www.golos.com.ua/article/296986 (дата обращения: 20.11.2020).

6. Трегуб Микола. URL: http://archive-uu.com/ua/profiles/mikolatregub/catalog/malyarstvo_Tr (дата обращения: 20.11.2020).

DOI https://doi.org/10.30525/978-9934-26-004-9-66

\title{
STAGES OF THE EXPERT STUDY OF GRAPHIC WORKS
}

\author{
Cherkashyna N. O. \\ Postgraduate Student \\ National Academy of Culture and Arts Management, \\ Chief Expert Forensic \\ Kharkiv Scientific Research Forensic Center \\ of the Ministry of Internal Affairs of Ukraine \\ Kharkiv, Ukraine
}

An expert examination is the action of a specialist aimed at establishing reliable and objective facts relating to an object of interest, with a view to establishing or confirming its veracity. In a broad sense, the concept of expertise means a certain set of specialist knowledge that allows to perform actions of a particular profile. Expert research is a complex process, the individual stages of which are interconnected and interdependent.

«Art examination is an independent type of examination during which the attribution and determination of the cultural and historical value of antiques or art objects are carried out» $[1$, p. 10]. Special recommendations on their handling, packaging, transportation and storage must be observed in the work with objects of art.

The following methods are used for expert studies:

- general (categories and laws of dialectical logic; formal cognitive methods: analysis, synthesis, generalization; induction and deduction, hypothesis; analogy and other); 